\title{
A breakthrough in gun control in Australia after the Port Arthur massacre
}

\author{
Rebecca Peters, Charles Watson
}

The Port Arthur massacre in Tasmania on 28-29 April 1996 killed 35 people and seriously injured 18 others. The death toll of 35 represents almost $50 \%$ of total firearm homicides for the entire country in an average year. Apart from the victims, their friends and families, the massacre has affected many others less directly. According to press reports, more than 2000 people, including 700 emergency workers, have required counselling and some were still too traumatised to return to work three months later. Several suicides have been allegedly linked to the tragedy. The financial cost, including losses to tourism, is estimated at \$A30 million over the next three years; a significant burden on a state with fewer than half a million people.

Australia has a mediocre record in gun control. Our firearm death rate of 30 per million population lies between the exemplary low rate in England and Wales (four per million) and the appallingly high rate in the USA (154 per million). Australia has about 600 firearm deaths per year, accounting for one in 13 of all injury deaths. Eighty per cent of gun deaths are suicides. Handguns are strictly controlled and cause fewer than 40 deaths each year. However, ownership of rifles and shotguns is fairly high, around four million guns in a population of 18 million.

Previous attempts to introduce significantly tighter gun laws have always been thwarted by the small but vocal gun lobby. In response to several mass shootings in the late $1980 \mathrm{~s}$, the National Committee on Violence (NCV) made 25 recommendations for gun law reform, the primary one being for a national gun control strategy based on uniform laws across the states. That suggestion, like most of the NCV's recommendations, was never acted on.

\section{Responses to the Port Arthur massacre} (1) POLITICAL RESPONSES

National Coalition for Gun Control, PO Box 167, Camperdown, NSW 2050, Australia R Peters

Faculty of Health and Behavioural Sciences, University of Wollongong, NSW 2522, Australia C Watson repeated, etc. However, these ritual lamentations fell short of specific commitments to gun law reform that might upset the shooting constituency.

It was at this point that a most unexpected thing happened. The newly elected conservative Prime Minister, John Howard, deeply moved by the tragedy, announced that he would do all in his power to tighten the gun laws. Even more surprisingly, he put immediate and unrelenting pressure on his conservative party colleagues around the nation to back him.

The problem for Howard was that under Australia's Constitution, the Federal Government has only limited power to control firearms. Almost all the significant powers to regulate the sale and possession of guns lie with the eight states and territories, so that any one state could torpedo the proposal by refusing to cooperate. It was only an extraordinary display of political determination and vision that enabled Howard to exert his will on all jurisdictions. On May 10, two weeks after Port Arthur, he convened a meeting of the Australian Police Ministers Council, where all states and territories signed an historic agreement to introduce strong uniform gun laws.

(2) THE RESPONSE OF THE GENERAL PUBLIC The initial horror and revulsion quickly turned to anger and a determination to tighten the gun laws. Opinion polls indicated that about $90 \%$ of Australians wanted tough gun laws, including registration of all guns and a total ban on semiautomatics. In the wake of the public surveys virtually every radio, television, and print media commentator began to give strong support for the Prime Minister's position.

\section{(3) THE RESPONSE OF THE GUN LOBBY}

Although $90 \%$ of Australians favoured tough new gun laws, the minority opposing this position was well funded and vocal. The gun lobby staged several large street demonstrations but media reports of immoderate and even reckless speeches actually assisted the case for gun control. The most notorious example was a speech by Ian McNiven, Vice President of the Firearm Owners' Association, in which he proclaimed that blood would have to be shed if the new gun laws were introduced. Such outbursts by extremists have made it difficult for the gun lobby to convince the public it is simply a group of rational, law abiding freedom lovers.
(4) THE RESPONSE OF PUBLIC HEALTH ORGANISATIONS

Only two health related organisations around Australia have made a significant contribution 
to the public debate in the four months after Port Arthur. They are the Coalition for Gun Control (a small voluntary organisation) and the Australian Medical Association. Not a single health department around Australia has made a significant contribution - due to a combination of lack of expertise and political compromise.

\section{The May 10 Agreement}

Prime Minister Howard put to the police ministers a 10 point plan for strict and uniform gun laws, based on the NCV recommendations. It requires every jurisdiction to pass laws that ensure:

- The sale and ownership of every gun must be registered in a national database.

- Anyone who wants to own a gun must prove they have a genuine reason; 'self defence' is not a genuine reason.

- The minimum age for a licence to own or buy guns will be 18 .

- New licence applicants will have to undertake a training course in gun safety.

- Domestic violence offenders will be banned from holding a gun licence for at least five years.

- Uniform and strict gun storage requirements will be instituted.

- Guns can only be bought and sold through licensed dealers - that is, no more mail order or backyard sales.

- As well as a licence, every purchase of a gun will require a permit with a 28 day waiting period.

- Semiautomatic weapons and pump-action shotguns will be banned, except for those farmers and professional shooters who can prove they have a genuine need for these weapons.

- Owners of prohibited weapons will have 12 months to surrender them for fair compensation, funded out of an increase in the Medicare levy (the universal tax surcharge that funds Australia's health care system).

After the amnesty, penalties for illegal ownership will be severe.

As well as creating a uniform scheme, these measures will raise the minimum standard of safety applying anywhere in Australia at pres- ent. The new laws will be tighter than the existing law in any state or territory.

\section{Clamping down on crimping}

Under pressure from the gun lobby, some members of John Howard's own government sought concessions. Weeks of public debate revolved around 'crimping', a proposal to modify semiautomatic shotguns by reducing the magazine capacity from five or 10 cartridges to two. Crimping advocates said the technique would allow these weapons no longer to be considered semiautomatics. However, the Prime Minister was not convinced that crimping was irreversible, so he refused to accept it. He correctly remarked that there was no doubt a long list of such hypothetical technical loopholes, but to accept them would be to let down the Australian people, who were united on the need to ban semiautomatics.

By mid-July three jurisdictions - Queensland, Western Australia, and the Northern Territory - still wanted to allow crimping. John Howard threatened that if all states did not fall into line, he would hold a national referendum to give the federal government power to pass one national gun law. Faced with this threat the recalcitrant states gave in.

\section{The future}

The Prime Minister has shown leadership and the police ministers courage in making the national agreement; and most Australians believe the battle for gun control has been won. Unfortunately, this is not true, as the new laws must now be passed by each state and territory parliament. The gun lobby will use all means available, including a great deal of money, to intimidate politicians at this level into weakening the laws with loopholes. As of mid-August 1996 three states - New South Wales, South Australia, and Tasmania - have passed satisfactory laws, though they have not set commencement dates.

The national response is a cultural turning point for Australia, an opportunity to become a society that does something about violence. It has provided an opportunity for our politicians to demonstrate maturity in finally putting party politics aside in the interest of public health. This is a landmark step for our democracy, putting an end to the power of the gun lobby to influence public policy through intimidation. 